Article

\title{
Phytochemical Characterization and Evaluation of the Antimicrobial, Antiproliferative and Pro-Apoptotic Potential of Ephedra alata Decne. Hydroalcoholic Extract against the MCF-7 Breast Cancer Cell Line
}

\author{
Corina Danciu ${ }^{1,+}{ }^{\dagger}$, Delia Muntean ${ }^{2,+}{ }^{,}$Ersilia Alexa ${ }^{3}$, Claudia Farcas ${ }^{4}$, Camelia Oprean ${ }^{5,6}$, \\ Istvan Zupko ${ }^{7}{ }^{(D}$, Andrea Bor ${ }^{7}$, Daliana Minda ${ }^{1, *}$, Maria Proks ${ }^{8}$, Valentina Buda ${ }^{8, *(D)}$, \\ Monica Hancianu ${ }^{9}$, Oana Cioanca ${ }^{9}$, Codruta Soica ${ }^{10}$, Sofia Popescu ${ }^{3}$ and \\ Cristina Adriana Dehelean 11 \\ 1 Department of Pharmacognosy, University of Medicine and Pharmacy "Victor Babeş", \\ Eftimie Murgu Square, No. 2, 300041 Timişoara, România; corina.danciu@umft.ro \\ 2 Department of Microbiology, University of Medicine and Pharmacy "Victor Babeş", Eftimie Murgu Square, \\ No. 2, 300041 Timişoara, România; muntean.delia@umft.ro \\ 3 Department of Food Control, Banat's University of Agricultural Sciences and Veterinary Medicine "King \\ Michael I of Romania" from Timisoara, Calea Aradului No. 119, 300641 Timisoara, Romania; \\ alexa.ersilia@yahoo.ro (E.A.); sofiapopescu@yahoo.com (S.P.) \\ 4 Department of Pharmaceutical Physics, University of Medicine and Pharmacy "Victor Babeş", Eftimie \\ Murgu Square, No. 2, 300041 Timişoara, România; farcas.claudia@umft.ro \\ 5 Department of Drug analysis; chemistry of the environment and food, University of Medicine and Pharmacy \\ "Victor Babeş", Eftimie Murgu Square, No. 2, 300041 Timişoara, România; camelia.oprean@umft.ro \\ 6 OncoGen Centre, County Hospital "Pius Branzeu", Blvd. Liviu Rebreanu 156, 300736 Timisoara, Romania \\ 7 Department of Pharmacodynamics and Biopharmacy, University of Szeged, Eötvös u. 6., \\ H-6720 Szeged, Hungary; zupko@pharm.u-szeged.hu (I.Z.); andrea.bor@pharm.u-szeged.hu (A.B.) \\ 8 Department of Pharmacology and Clinical Pharmacy, University of Medicine and Pharmacy "Victor Babeş", \\ Eftimie Murgu Square, No. 2, 300041 Timişoara, România; proks.maria@yahoo.ro \\ 9 Department of Pharmacognosy, Faculty of Pharmacy, “Grigore T.Popa” University of Medicine and \\ Pharmacy, 700115 Iasi, Romania; mhancianu@yahoo.com (M.H.); oana.cioanca@gmail.com (O.C.) \\ 10 Department of Pharmaceutical chemistry, University of Medicine and Pharmacy "Victor Babeş", \\ Eftimie Murgu Square, No. 2, 300041 Timişoara, România; codrutasoica@umft.ro \\ 11 Department of Toxicology, University of Medicine and Pharmacy "Victor Babeş", Eftimie Murgu Square, \\ No. 2, 300041 Timişoara, România; cadehelean@umft.ro \\ * Correspondence: daliana.minda@umft.ro (D.M.); buda.valentina.oana@gmail.com (V.B.); \\ Tel.: +4075-5100-408 (D.M.); +4074-7374-297 (V.B.) \\ + These authors contribute equally to this work.
}

Academic Editors: Natália Martins and Gertjan van Dijk

Received: 21 November 2018; Accepted: 19 December 2018; Published: 20 December 2018

check for updates

\begin{abstract}
Ephedra alata Decne. belongs to the Ephedraceae family. It is a species of Ephedra that grows mostly in the desert. Today, the main importance of Ephedra species in the medical field is due to the presence of the alkaloids derived from phenyl-alanine, which act on the sympathetic nervous system as a sympathomimetic. The aim of this study was to conduct a phytochemical characterization of the hydroalcoholic extract of the aerial part of Ephedra alata Decne., which is indigenous to Tunis, that involves the total phenolic content, individual phenolic content, and antioxidant activity as well as a biological screening for the evaluation of the antimicrobial, antifungal, antiproliferative, pro-apoptotic, and cytotoxic potential against the MCF-7 breast cancer cell line. The results show that the hydroalcoholic extract contains polyphenolic phytocompounds (156.226 $\pm 0.5 \mathrm{mgGAE} / \mathrm{g}$ extract) and elicits antioxidant activity (7453.18 $\pm 2.5 \mu \mathrm{mol}$ Trolox/g extract). The extract acted as a bacteriostatic agent against all tested bacterial strains, but was bactericidal only against the Gram-positive cocci and Candida spp. In the set experimental parameters, the extract presents
\end{abstract}


antiproliferative, pro-apoptotic, and cytotoxic potential against the MCF-7 human breast cancer cell line.

Keywords: Ephedra alata Decne; polyphenols; antioxidant; bacteria; fungi; MCF-7 human breast cancer cell line

\section{Introduction}

Throughout history, the Plant Kingdom has represented a significant source for the discovery of new drugs with important therapeutic effects in different areas of medicine. Various types of plant extracts include a large range of phytochemicals, which can be-on their own or through a synergistic mechanism-useful for different therapeutic activities. At the moment, many of the currently used drugs in well-established therapeutic protocols are directly obtained from, or are chemical derivatives of, phytochemicals [1].

Ephedra alata Decne. belongs to the Ephedraceae family. It is a species of Ephedra that grows mostly in the desert. The genus Ephedra is known to comprise approximately 40 species that populate arid environments, especially those from the northern hemisphere and the south part of America [2]. Ephedra species have a long history in traditional Chinese medicine (approximately 5000 years), with uses in the treatment of allergies, nasal congestion, bronchial asthma, coughs, and flu [3]. The drug is known under the name of Ma-huang. The drug was traditionally obtained from the dry stems of three Ephedra species, namely Ephedra sinica, Ephedra intermedia, and Ephedra equisetina, and is nowadays sold in health food stores in the West as a herbal mixture, known under the name of Herbal Ecstasy, that is proclaimed to have energizing value [4]. Today, the main importance of Ephedra species in the medical field is due to the presence of the alkaloids derived from phenyl-alanine (e.g., ephedrine and other related compounds, such as pseudoephedrine, norpseudoephedrine, norephedrine, methylephedrine, and methylpseudoephedrine), which acts on the sympathetic nervous system as a sympathomimetic [5]. It was reported in the literature that the aerial parts of this plant contain between 0.02 and $3.4 \%$ nitrate compounds, with (-)ephedrine being the main isomer detected (between 30 and 90\%) [6]. Ephedrine is a medicine that is used to prevent arterial hypotension during spinal anesthesia. It is commonly employed as nasal decongestant, and has appetite-suppressant properties [7]. Besides this class of phytochemicals, the plant extract represents a source of polyphenolic compounds, which provide it with significant antioxidant properties [8]. Flavones, flavanols, bisflavanols, and carboxylic acids were reported to be the main phytochemicals along with alkaloids by the group of Abourashed et al. [6]. Also, essential oil has been indicated to be among the main components of this plant [9].

The literature describes some studies on the biological activity of Ephedra species. Extracts or fractions from callus cultures or wild plants from different species of Ephedra were reported to have antioxidant, antimicrobial, and antifungal properties [10,11]. Pullela et al. have isolated four lignans from Ephedra viridis Coville and screened these compounds for antioxidant and estrogenic activity and a possible cytotoxic effect against a number of human leukemia cells and solid tumors. The study concluded that the compounds elicited moderate free radical scavenging properties, no cytotoxicity, and estrogenic activity [12]. Nam et al. have shown that a water fraction of Ephedra sinica Stapf. has manifested anti-invasive, antiangiogenic, and antitumour effects in a mouse model of murine melanoma [13]. The hydroalcoholic extract obtained from Ephedra campylopoda C.A.Mey. has been assigned antioxidant, antibacterial, and in vitro antiproliferative properties against the HT 29 and HCT 116 colon cancer cell lines [14]. Ephedra fragilis Desf. extract elicited immunostimulant activity in an in vitro model using human peripheral lymphocytes [15]. Ephedra alata L. turned out to be a promising agent for a biologically based strategy for the inhibition of growth as well as aflatoxin production by Aspergillus flavus mold [16]. 
The aim of this study was to conduct a phytochemical characterization of the hydroalcoholic extract of the aerial part Ephedra alata Decne., which is indigenous to Tunis, that involves the total polyphenols content, individual polyphenols content, and antioxidant activity as well as a biological screening for an evaluation of the extract's antimicrobial, antifungal, antiproliferative, pro-apoptotic, and cytotoxic potential against the MCF-7 breast cancer cell line.

\section{Results}

\subsection{Phytochemical Composition}

In order to determine the phytochemical composition, the total phenolic content (TP), individual phenolic content, antioxidant activity (AA), and total alkaloids (TA) were screened. The phytochemical composition of the hydroalcoholic extract of the aerial part of Ephedra alata Decne. (EA), determined by UV-VIS spectrometry, is presented in Table 1. The individual polyphenols and LC-MS parameters of the hydroalcoholic extract of the aerial part of Ephedra alata Decne. (EA) are presented in Table 2.

Table 1. The total phenolic content (TP), antioxidant activity (AA), and total alkaloids (TA) of the hydroalcoholic extract of the aerial part of Ephedra alata Decne. (EA).

\begin{tabular}{cccc}
\hline Sample & $\begin{array}{c}\text { TP } \\
\text { (mgGAE/g Extract) }\end{array}$ & $\begin{array}{c}\text { AA } \\
(\mu \text { mol Trolox/g Extract) }\end{array}$ & $\begin{array}{c}\text { TA } \\
\text { (mg Ephedrine/g Extract) }\end{array}$ \\
\hline EA & $156.226 \pm 0.5$ & $7453.18 \pm 2.5$ & $17.57 \pm 0.6$ \\
\hline
\end{tabular}

The individual polyphenols were detected using different extraction conditions and identified on two different chromatographic columns (Figure 1 and Table 2). The screened compounds were gallic acid, protocatecuic acid, caffeic acid, coumaric acid, ferulic acid, rosmarinic acid, epicatechin, rutin, resveratrol, quercetin, and kaempherol.

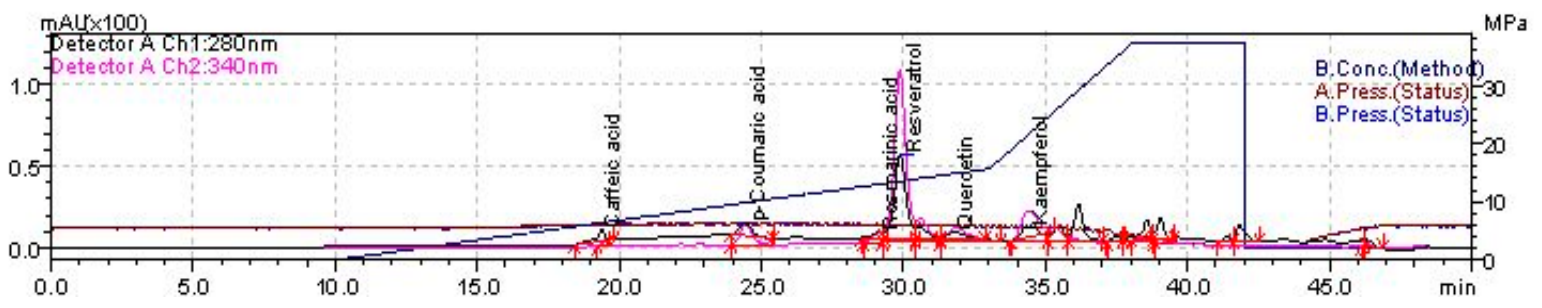

(A) Extract obtained in 70\% ethanol and chromatographic conditions on column I.

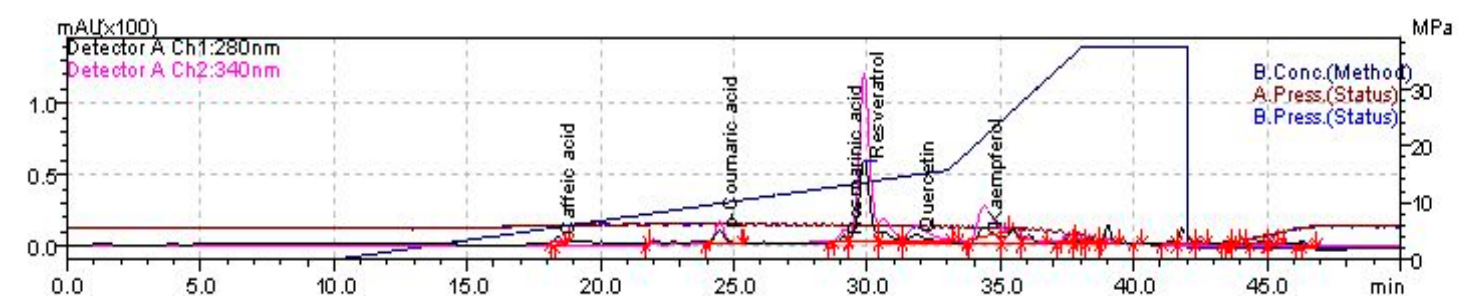

(B) Extract obtained in methanol:water:formic acid (90:10:2, v/v/v) and chromatographic conditions on column I.

Figure 1. An LC-MS chromatogram of the hydroalcoholic extract of the aerial part of Ephedra alata Decne. (EA). 
Table 2. The individual polyphenols of the hydroalcoholic extract of the aerial part of Ephedra alata Decne. (EA), and the LC-MS parameters.

\begin{tabular}{|c|c|c|c|c|c|c|c|}
\hline Compounds & $\begin{array}{l}\text { Retention } \\
\text { Time } \\
\text { Column I } \\
\text { (min) }\end{array}$ & $\begin{array}{l}\text { Retention } \\
\text { Time } \\
\text { Column II } \\
\text { (min) }\end{array}$ & $\begin{array}{c}\mathrm{m} / \mathbf{z} \\
\text { Signal }\end{array}$ & $\begin{array}{l}\text { EA in Hydroe } \\
\text { Column I } \\
\mu \mathrm{g} / \mathrm{mL} \pm \mathrm{SD} \\
(\mu \mathrm{g} / \mathrm{mg})\end{array}$ & $\begin{array}{l}\text { Tanolic Extract } \\
\text { Column II } \\
\mu \mathrm{g} / \mathrm{mL} \pm \mathrm{SD} \\
(\mu \mathrm{g} / \mathrm{mg})\end{array}$ & $\begin{array}{c}\text { EA in Hydromethanolic Extract } \\
\text { Chromatographic Column I } \\
(\mu \mathrm{g} / \mathrm{mL} \pm \mathrm{SD})(\mu \mathrm{g} / \mathrm{mg})\end{array}$ & $\begin{array}{l}\text { Calibration } \\
\text { Curve }\end{array}$ \\
\hline Gallic acid & 4.826 & 4.745 & 169 & nd & nd & nd & $\begin{array}{c}\mathrm{y}=8.470 \mathrm{e}-006 \mathrm{x} \\
\quad(\mathrm{r}=0.9996) ;\end{array}$ \\
\hline Protocatecuic acid & 11.982 & 11.774 & 153 & nd & nd & nd & $\begin{array}{c}\mathrm{y}=8.036 \mathrm{e}-006 \mathrm{x} \\
\quad(\mathrm{r}=0.9990)\end{array}$ \\
\hline Caffeic acid & 18.605 & 18.396 & 179 & $\begin{array}{c}0.709 \pm 0.279 \\
(0.014)\end{array}$ & nd & $0.389 \pm 0.49(0.008)$ & $\begin{array}{c}\mathrm{y}=7.110 \mathrm{e}-006 \mathrm{x} \\
\quad(\mathrm{r}=0.9990)\end{array}$ \\
\hline Epicatechin & 22.910 & 23.242 & 289 & nd & $\begin{array}{c}7.736 \pm 0.297 \\
(0.155)\end{array}$ & nd & $\begin{array}{c}\mathrm{y}=3.881 \mathrm{e}-005 \mathrm{x} \\
\quad(\mathrm{r}=0.9996) ;\end{array}$ \\
\hline p-coumaric acid & 24.374 & 24.454 & 163 & $\begin{array}{c}0.241 \pm 0.028 \\
(0.005)\end{array}$ & nd & $0.261 \pm 0.021(0.005)$ & $\begin{array}{c}y=1.1566 \mathrm{e}-006 \mathrm{x} \\
\quad(\mathrm{r}=0.9997) ;\end{array}$ \\
\hline Ferulic acid & 26.333 & 24.883 & 193 & nd & nd & nd & $\begin{array}{c}\mathrm{y}=1.172 \mathrm{e}-006 \mathrm{x} \\
\quad(\mathrm{r}=0.9999)\end{array}$ \\
\hline Rutin & 27.290 & 26.086 & 609 & nd & nd & nd & $\begin{array}{c}\mathrm{y}=1.813 \mathrm{e}-005 \mathrm{x} \\
(\mathrm{r}=0.9999)\end{array}$ \\
\hline Rosmarinic acid & 28.252 & 29.129 & 359 & $\begin{array}{c}0.915 \pm 0.008 \\
(0.018)\end{array}$ & $\begin{array}{c}0.397 \pm 0.002 \\
(0.008)\end{array}$ & $0.807 \pm 0.049(0.016)$ & $\begin{array}{c}\mathrm{y}=1.018 \mathrm{e}-006 \mathrm{x} \\
\quad(\mathrm{r}=0.9982)\end{array}$ \\
\hline Resveratrol & 29.749 & 29.887 & 227 & $\begin{array}{c}9.403 \pm 0.008 \\
(0.188)\end{array}$ & $\begin{array}{c}12.963 \pm 0.454 \\
(0.259)\end{array}$ & $10.387 \pm 0.422(0.207)$ & $\begin{array}{c}\mathrm{y}=6.388 \mathrm{e}-006 \mathrm{x} \\
\quad(\mathrm{r}=0.9945)\end{array}$ \\
\hline Quercitin & 32.591 & 31.841 & 301 & $\begin{array}{c}2.873 \pm 0.70 \\
(0.057)\end{array}$ & $\begin{array}{c}2.387 \pm 0.06 \\
(0.048)\end{array}$ & $4.572 \pm 0.384(0.091)$ & $\begin{array}{c}\mathrm{y}=1.001 \mathrm{e}-005 \mathrm{x} \\
\quad(\mathrm{r}=0.9992)\end{array}$ \\
\hline Kaempferol & 34.470 & 34.378 & 285 & $\begin{array}{c}24.297 \pm 2.73 \\
(0.485)\end{array}$ & $\begin{array}{c}6.814 \pm 0.179 \\
(0.136)\end{array}$ & $28.675 \pm 2.579(2.867)$ & $\begin{array}{c}y=3.273 e-005 x \\
\quad(r=0.9990) .\end{array}$ \\
\hline
\end{tabular}

nd $=$ not detected.

In the ethanolic extracts of EA, individual polyphenols were determined using two different C18 chromatographic columns under the same operating conditions. The compounds identified on both columns were: rosmarinic acid (mean value, $0.013 \mu \mathrm{g} / \mathrm{mg}$ ), resveratrol $(0.223 \mu \mathrm{g} / \mathrm{mg})$, quercitin $(2.63$ $\mu \mathrm{g} / \mathrm{mg})$, and kampherol $(15.55 \mu \mathrm{g} / \mathrm{mg})$. Caffeic acid $(0.014 \mu \mathrm{g} / \mathrm{mg})$ and p-coumaric acid $(0.05 \mu \mathrm{g} / \mathrm{mg})$ were identified in small quantities. These compounds were identified only on the Adsorbosphere UHS C18 column, while epicatechin was identified on the NUCLEODUR C18 Gravity SB column.

In the methanolic extract, rosmarinic acid $(0.016 \mu \mathrm{g} / \mathrm{mg})$, resveratrol $(0.207 \mu \mathrm{g} / \mathrm{mg})$, quercitin $(0.091 \mu \mathrm{g} / \mathrm{mg}), \mathrm{kampherol}(2.867 \mu \mathrm{g} / \mathrm{mg})$, caffeic acid $(0.008 \mu \mathrm{g} / \mathrm{mg})$, and p-coumaric acid $(0.005$ $\mu \mathrm{g} / \mathrm{mg}$ ) were detected. Gallic acid, protocatechuic acid, and ferulic acid were not detected in either of the two analyzed extracts.

\subsection{Antimicrobial Activity}

Another aim of the study was to screen EA for antimicrobial activity. The antibacterial activity of this extract was established according to the standardized value of the positive control $(15 \mathrm{~mm}$ for gentamycin and $17 \mathrm{~mm}$ for fluconazole). All Gram-negative bacilli strains and Enterococcus faecalis were resistant to the test extract. The Staphylococcus aureus and Candida strains had insignificant inhibitory activity at the screened concentration. The inhibition diameters are presented in Table 3.

Table 3. The inhibition diameters for selected strains after incubation with $30 \mu \mathrm{g} / \mathrm{ml}$ of EA.

\begin{tabular}{|c|c|c|c|c|c|c|c|c|c|}
\hline Compound & $\begin{array}{c}\text { Klebsiella } \\
\text { Pneumonia }\end{array}$ & $\begin{array}{l}\text { Shigella } \\
\text { flexneri }\end{array}$ & $\begin{array}{l}\text { Salmonella } \\
\text { Enterica }\end{array}$ & $\begin{array}{l}\text { Escherichia } \\
\text { coli }\end{array}$ & $\begin{array}{c}\text { Pseudomonas } \\
\text { Aeruginosa }\end{array}$ & $\begin{array}{c}\text { Staphylococcus } \\
\text { Aureus }\end{array}$ & $\begin{array}{c}\text { Enterococcus } \\
\text { Faecalis }\end{array}$ & $\begin{array}{l}\text { Candida } \\
\text { Albicans }\end{array}$ & $\begin{array}{c}\text { Candida } \\
\text { Parapsilosis }\end{array}$ \\
\hline$E A$ & $7 \mathrm{~mm}$ & $7 \mathrm{~mm}$ & $7 \mathrm{~mm}$ & $7 \mathrm{~mm}$ & $7 \mathrm{~mm}$ & $9 \mathrm{~mm}$ & $7 \mathrm{~mm}$ & $10 \mathrm{~mm}$ & $10 \mathrm{~mm}$ \\
\hline
\end{tabular}

Table 4 presents the results on the MIC and MBC. The MIC values for S. aureus and Candida spp. $(50 \mu \mathrm{g} / \mathrm{mL})$ were lower than those for Gram-negative bacteria $(200 \mu \mathrm{g} / \mathrm{mL})$ and E. faecalis $(100 \mu \mathrm{g} / \mathrm{mL})$. In addition, the MBC values were 2 times greater than the MIC values. Based on these results, we can affirm that the extract can act as a bacteriostatic agent against all tested bacterial strains; however, it is bactericidal only against the Gram-positive cocci and Candida spp. 
Table 4. The Results on the minimum inhibitory concentration (MIC) and the minimum bactericidal concentration $(\mathrm{MBC})$.

\begin{tabular}{ccc}
\hline Species & MIC $(\mu \mathrm{g} / \mathrm{mL})$ & MBC $(\mu \mathrm{g} / \mathrm{mL})$ \\
\hline K. pneumoniae & 200 & - \\
S. flexne & 200 & - \\
S. enterica & 200 & - \\
E. coli & 200 & - \\
P. aeruginosa & 200 & - \\
S. aureus & 50 & 100 \\
E. faecalis & 100 & 200 \\
C. albicans & 50 & 100 \\
C. parapsilosis & 50 & 100 \\
\hline
\end{tabular}

\subsection{Anticancer Activity}

The EA was screened for possible in vitro anticancer activity against the MCF-7 human breast cancer cell line. The antiproliferative activity of EA at the selected concentrations after a period of incubation of $72 \mathrm{~h}$ is shown in Figure 2. Statistically significant results were detected starting from the concentration of $10 \mu \mathrm{g} / \mathrm{mL}$, with a cell growth inhibition percentage of $19.68 \pm 4.2$. For the highest tested concentration, namely $30 \mu \mathrm{g} / \mathrm{mL}$, the growth inhibition percentage was $56.45 \pm 3.9$.

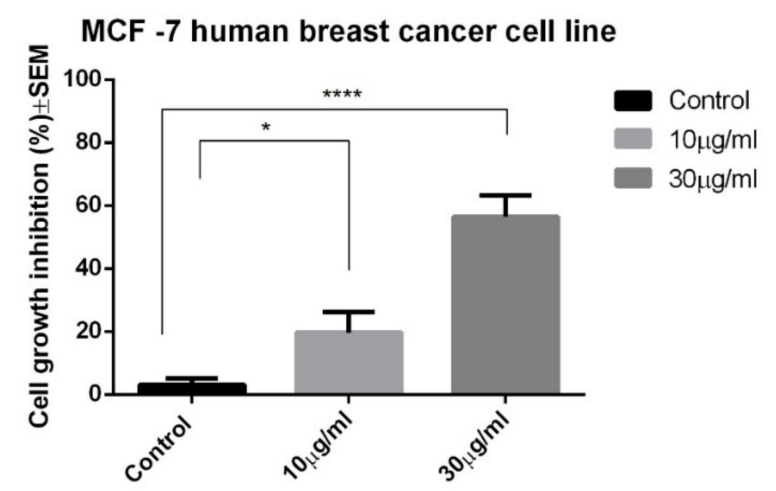

Figure 2. The cell growth inhibition for the MCF-7 human breast cancer cell line after $72 \mathrm{~h}$ of incubation with EA. SEM, standard error of the mean.

As is already well-known, MTT is a colorimetric assay for assessing the metabolic activity of cells (the activity of mitochondrial dehydrogenase). In order to see if we can also talk about a possible cytotoxic effect, the release of lactat dehydrogenase at the highest tested concentration was also measured. The results are depicted in Figure 3.

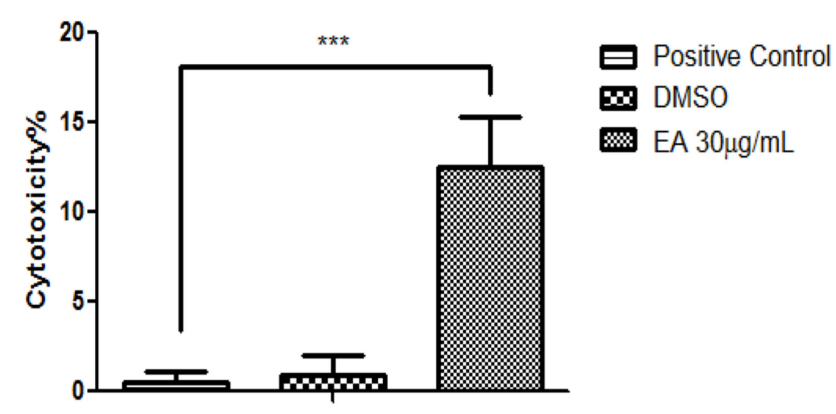

Figure 3. The cytotoxicity analysis of EA extract at a concentration of $30 \mu \mathrm{g} / \mathrm{mL}$ on MCF-7 cells (after $72 \mathrm{~h}$ of stimulation). 
The cytotoxicity assessment revealed that the EA extract manifested a significant difference in cytotoxic potential when compared with the positive control, displaying a cytotoxicity percentage above 13\%. The solvent (DMSO) showed no significant cytotoxic potential on MCF-7 cells.

The distribution of the phases of the cell cycle following incubation with EA at the concentration of $30 \mu \mathrm{g} / \mathrm{ml}$ shows a slight increase in the percentage of cells of the G0/G1 phase (data not shown).

The potential anti-migratory activity of the EA on MCF-7 human breast adenocarcinoma cells was verified by means of a wound-healing technique, and the results are shown in Figure 4.
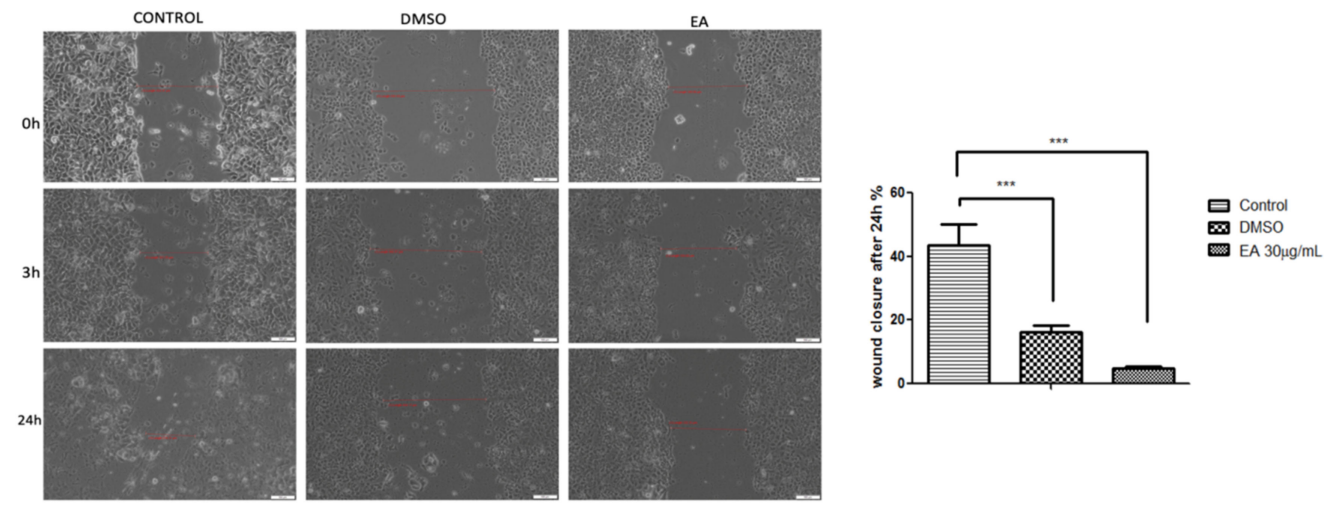

Figure 4. The migratory potential of MCF-7 human breast adenocarcinoma cells after treatment with EA extract at a concentration of $30 \mu \mathrm{g} / \mathrm{mL}$. The pictures were taken by light microscopy, and the scale bars represent $100 \mu \mathrm{m}$. The bar graphs are expressed as percentage of wound healing after $24 \mathrm{~h}$ compared to the initial surface.

The results indicate that the EA extract had a strong inhibitory effect on the MCF-7 cells' migration, showing a wound healing rate below 5\% after an interval of $24 \mathrm{~h}$. The solvent (DMSO) was also analysed for potential anti-migratory activity. It can be observed from Figure 4 that the solvent slowed down the migratory potential of the MCF-7 cells, inducing a wound closure percentage of almost $17 \%$. The control cells (cells treated with growth medium) showed a closure of the scratch above $43 \%$.

The cytotoxicity assessment revealed that the EA extract manifested a significant difference in the cytotoxic potential when compared to the positive control, displaying a cytotoxicity percentage above 13\%. The solvent (DMSO) showed no significant cytotoxic potential on MCF-7 cells.

In order to investigate the apoptotic potential of EA at the selected concentration, MCF-7 cells were treated with $30 \mu \mathrm{g} / \mathrm{mL}$ of EA for $72 \mathrm{~h}$, and the cells' nuclei were analyzed by DAPI staining. As shown in Figure 5, the control cells exhibit a normal organization, with a large, round nucleus, a clear nucleolus, and uniform chromatin density. However, after treatment, the MCF-7 cells manifested morphological changes distinctive for apoptosis induction, such as chromatin condensation.
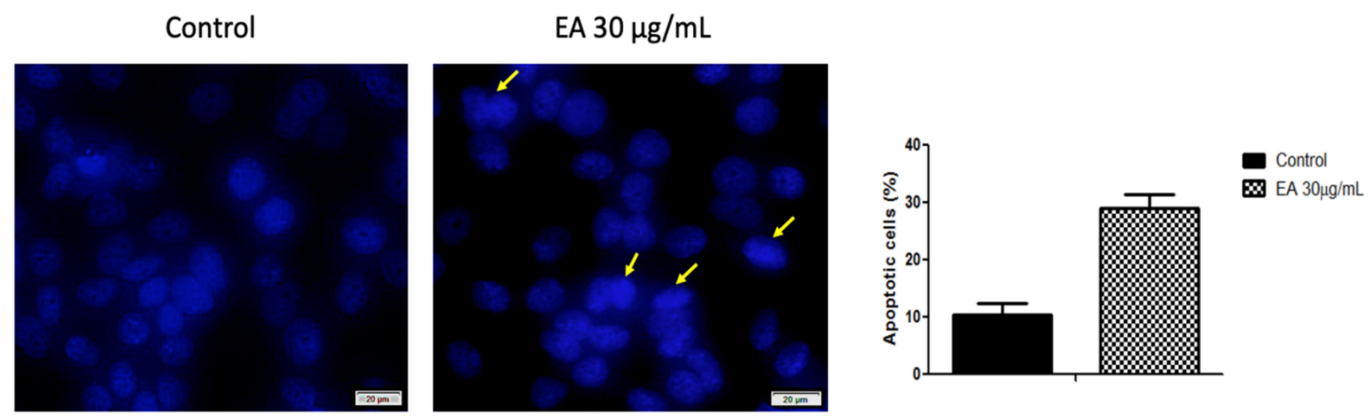

Figure 5. The effect of $30 \mu \mathrm{g} / \mathrm{mL}$ of EA on MCF-7 cells' nuclei after $72 \mathrm{~h}$. Morphological changes distinctive for apoptosis induction are marked with yellow arrows. For the nuclear visualization, DAPI staining was performed. The scale bars represent $20 \mu \mathrm{m}$. 
Figure 6 presents the evaluation of the pro-apoptotic activity of the MCF-7 human breast cancer cell line after $72 \mathrm{~h}$ of incubation with EA at the concentration of $30 \mu \mathrm{g} / \mathrm{mL}$ (mean values) together with representative dot-plots. Early apoptosis, late apoptosis, and necrosis can be detected. The highest number of events was recorded for the process of early apoptosis.

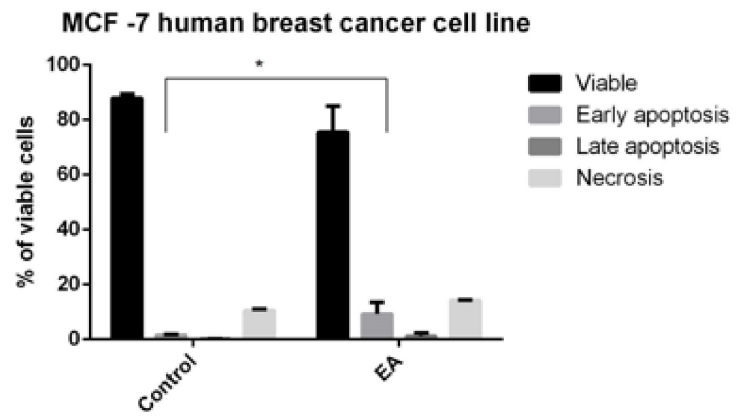

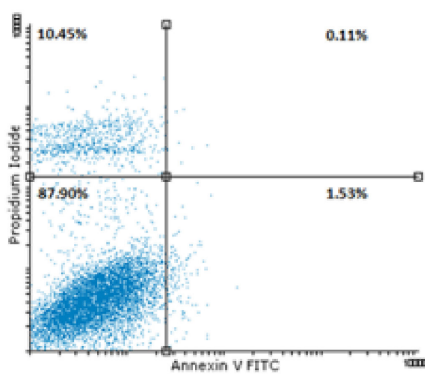

Control

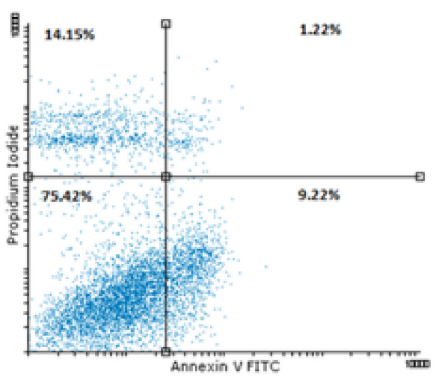

$30 \mu \mathrm{g} / \mathrm{ml} \mathrm{EA}$

Figure 6. The evaluation of the pro-apoptotic activity of the MCF-7 human breast cancer cell line after $72 \mathrm{~h}$ of incubation with EA at the concentration of $30 \mu \mathrm{g} / \mathrm{mL}$ (lower right quadrant: early apoptotic cells; upper right quadrant: late apoptotic cells; upper left quadrant: necrotic cells).

\section{Discussion}

The results obtained in this study regarding the phytochemical composition-TA $(17.57 \mathrm{mg} / \mathrm{g}$ extract), TP (156.22 mgGAE/g extract), and AA (7453 $\mu \mathrm{mol}$ Trolox/g)—are consistent with those reported by other authors.

In a comprehensive study on the phytochemical composition of different Ephedra species collected from the botanical garden of the University of Hamburg, Germany and analyzed as methanolic extracts, Ibragic and Sofic 2015 have reported the total phenolics content (TP, $53.3 \pm 0.1 \mathrm{mg}$ GAE/g dry weight) and total alkaloids content (TA, 0.2-15.24 mg E/g dry weight) [5].

The group of Jaradat et al. have analyzed the phytochemical composition of the same species collected from the mountains of Jenin region, Palestine using water, methanol, and ethanol for the extraction. The study reports that, when water was used, total polyphenols could not be detected in the extract, while small amounts of flavonoids were detected $(0.519 \pm 0.09 \mathrm{mg} / \mathrm{g}$ Rutin equivalent). Methanol was found to be the best solvent, leading to $47.62 \pm 0.94 \mathrm{mg}$ GAE/g dry weight of total polyphenols and $54.66 \pm 0.12 \mathrm{mg} / \mathrm{g}$ Rutin equivalent of total flavonoids. Ethanol had a mild extraction capacity, leading to $19.175 \pm 0.62594 \mathrm{mg}$ GAE/g dry weight of total polyphenols and $5.44 \pm 0.625 \mathrm{mg} / \mathrm{g}$ Rutin equivalent of total flavonoids. The antioxidant activity of the extract was ascertained by a DPPH assay [17]. Jerbi et al. tested different solvents, namely hexane, ethyl acetat, and methanol, for the extraction, and recorded the highest percentage yield of extraction as well as the highest radical scavenging potential when methanol was employed [9]. It is well-known that evaporation leads to solvent removal; however, evaporation may not lead to 100\% removal, as trace amounts of solvent can remain. Although the abovementioned studies showed that methanol extracts better than ethanol, which is an event that is expected due to polarity, we have chosen ethanol as the solvent in this study 
because of its lack of toxicity within an in vivo environment. In a similar approach, the group of Al-Rimawi et al. analyzed extracts of Ephedra alata Decne. collected from the southern part of the West Bank, Palestine using three different solvents, namely water, 100\% ethanol, and 80\% ethanol, in order to observe which solvent leads to the highest amount of total polyphenols (TP), the highest amount total flavonoids (TF), and the highest antioxidant activity (AA). The results showed that the polarity influences the screened parameters, with $80 \%$ ethanol being the best choice in terms of TP (101.2 \pm $0.9 \mathrm{mg}$ GAE $/ \mathrm{g}$ dry weight) and AA (FRAP, $21.3 \pm 0.4 \mathrm{mmol}$ Fe+2/g dry weight; CUPRAC, $6442 \pm 52$ $\mu \mathrm{mol}$ Trolox/g dry weight; DPPH, $482.5 \pm 1.7 \mu \mathrm{mol}$ Trolox/g dry weight; and ABTS, $66.0 \pm 1.5 \mu \mathrm{mol}$ Trolox/g dry weight). On the other hand, the TF was higher in case of $100 \%$ ethanol (19.5 $\pm 0.3 \mathrm{mg}$ catechin/g dry weight) [18].

The Ephedra genus is recognized for its high alkaloid content; in particular, alkaloids belonging to the ephedrine (E) type. However, a small number of studies point towards the composition of individual polyphenols. In this respect, this paper presents a new approach regarding the phytochemical composition of EA.

Amakura et al. reported on the main individual polyphenols in EA (cinnamic acid, syringin, catechin, epicatechin, symplocoside, pollenitin B, herbacetin 7-O-glucoside, kaempferol 3-O-rhamnoside 7-O-glucoside, and isovitexin 2-O-rhamnoside) [19]. The LC-DAD-ESI/MSn profile of E. alata was characterized by Ziani et al. It indicated the presence of 10 phenolic compounds, all belonging to the flavonoids class (five isoflavones and five flavones) [20]. Quercitin and kaempferol-3-O-rhamnoside have also previously been detected in Ephedra dietary supplements [21].

Our results on the polyphenols identified in the hydroalcoholic extracts of EA are consistent with previous data reported by other researchers, and indicate the presence of quercitin and kaempferol. The presence of rosmarinic acid in the hydroalcoholic extracts of EA represents a particularity that has not been reported in previous studies.

\section{Antimicrobial Activity}

There is a paucity of studies in the literature on the antimicrobial activity of Ephedra alata Decne. A few groups, including that of Ghanem et al., have evaluated the antimicrobial activity of different types of extracts from Ephedra alata, namely water, methanol, and acetonitrile extracts, against four bacteria (S. aureus, Pseudomonas aeruginosa, Bacillus subtilis, and Escherichia coli) and four fungi (Aspergillus fumigatus, Penicillium italicum, Syncephalastrum racemosum, and C. albicans). The results showed that the only extract that was active against both Gram-positive and Gram-negative bacteria, as well as against fungi, was the acetonitrile extract. The methanolic extract elicited only antifungal potential, with $A$. fumigatus and $P$. italicum being the sensitive strains [22]. Good results for both Gram-positive and Gram-negative bacteria were obtained with the following solvents: butanol, ethyl acetate, and dichloromethane [23]. In this study, which analyses the ethanolic extract obtained from the aerial part of Ephedra alata Decne., we have shown that, among the tested strains, S. aureus and Candida spp. are the most sensitive strains to EA.

Some species of Ephedra have been assigned anticancer potential against various cell lines. For example, extracts obtained with different solvents from Ephedra aphylla have shown antiproliferative activity against the T47D and MCF-7 breast cancer cell lines. The same study showed that the extracts have weak antiproliferative potential against Vero, a normal kidney cell line [24]. Ephedra campylopoda stem methanolic and ethanolic extracts elicited an antiproliferative effect on the Jurkat human leukemic T cell line [25]. The herbal extract of Ephedra initially obtained from Ephedra sinica, as well as an ephedrine alkaloid-free Ephedra herb extract, has shown antiproliferative potential against the H1975 non-small-cell lung cancer cell line [26]. Mohamad et al. have presented data on the antiproliferative effect of Ephedra campylopoda collected from the south of Lebanon on HT-29 human epithelial cells and HCT116 human colon cancer cells [14]. The cytotoxic effect (at $24 \mathrm{~h}$ of incubation) and cytostatic effect (at $72 \mathrm{~h}$ of incubation) of Ephedra alata extracts in the range of $0-1000 \mu \mathrm{g} / \mathrm{mL}$ were analyzed for monocultures and co-cultures of Hepg2 and THP-1-derived 
macrophages. Significant cytotoxic effects were recorded for concentrations higher than $500 \mu \mathrm{g} / \mathrm{mL}$. The cytostatic activity was stronger in the co-cultures (an $\mathrm{IC}_{50}$ of $380 \mu \mathrm{g} / \mathrm{mL}$ ) [27]. Mendelovich et al. have shown that ethanolic extracts from the leaves, as well as the fruit juice, of Ephedra foeminea have significant antiproliferative and pro-apoptotic potential against MDA-MB-231 (human breast cancer), HCT116 (human colon) and HaCaT (human keratinocytes) cells [28]. In an ethnopharmacological study, Jaradat et al. concluded, based on questionnaires addressed to women diagnosed with breast cancer on the West Bank of Palestine, that the leaves and seeds of Ephedra alata, mostly prepared in the form of a decoction, are the most frequently used vegetal products in the treatment of breast cancer [29]. In a more comprehensive ethnopharmacological study conducted in the same region that included 150 herbalists, traditional healers, and rural dwellers, Jaradat et al. statistically observed that 72 plants have been employed for treatment of this pathology, with the most represented families being Compositae and Lamiaceae. The analysis showed that lung cancer was the type of malignancy most often treated with plants, and that Ephedra alata was the most frequently used phytomedicine for the management of cancer in Palestine [30,31]. The novelty of this study from the point of view of anticancer evaluation is the fact that, in the set experimental parameters, EA exhibits important antiproliferative, and weak pro-apoptotic and cytotoxic, potential against the MCF-7 human breast cancer cell line. So, the results from the abovementioned ethnopharmacological studies are supported by our experimental data, which attest to the in vitro anticancer activity of EA by mechanisms that involve the inhibition of proliferation.

\section{Materials and Methods}

\subsection{Plant Materials}

Dried aerial parts of Ephedra alata Decne. were bought in Romania from the southern part of Tunisia (Djerba) by a student of the Victor Babeş University of Medicine and Pharmacy, identified in the department of Pharmacognosy, and assigned the voucher specimen code Ea 12/2018. Some of the dried aerial parts were ground with the help of a commercial blender. From the powder, $10 \mathrm{~g}$ were weighted, and $50 \mathrm{~mL}$ of $70 \%$ ethanol were added. The extraction was conducted in an ultrasonic bath (FALC LBS2, Treviglio, Italia) for $30 \mathrm{~min}$ at a frequency of $40 \mathrm{kHz}$ and a temperature of $50^{\circ} \mathrm{C}$. The extract was then filtered with a vacuum pump. The solvent was evaporated to dryness in a rotary evaporator ( 250 bar pressure, temperature $60^{\circ} \mathrm{C}$, and $150 \mathrm{rpm}$ ). The extract (EA) was stored at $-4^{\circ} \mathrm{C}$ until use.

\subsection{Determination of Total Polyphenols Content (TP)}

From the previously obtained extract, $0.1 \mathrm{~g}$ were dissolved in $1 \mathrm{~mL}$ methanol and ultrasonicated for 30 min using an Aqua Wave 9381 (Barnstead Lab Line, Thermo Fisher Inc.). A 0.5 mL amount of alcoholic extract was treated with $1.25 \mathrm{~mL}$ of Folin-Ciocalteu (Merck, Darmstadt, Germany) reagent diluted 1:10 with water. The sample was incubated for $5 \mathrm{mins}$ at room temperature, and $1 \mathrm{~mL} \mathrm{of} 60 \mathrm{~g} / \mathrm{L}$ $\mathrm{Na}_{2} \mathrm{CO}_{3}$ (S.C.Chemical Company S.A., Bucuresti, Romania) was added. After 30 min of incubation at $50{ }^{\circ} \mathrm{C}$, the absorbance of the samples was measured at $750 \mathrm{~nm}$ using a UV-VIS spectrophotometer (Analytic Jena Specord 205, Jena, Germany). The calibration curve was obtained using gallic acid (GA) (Sigma Aldrich Chemie, Madrid, Spain) as a standard (concentration range 5-250 $\mu \mathrm{g} / \mathrm{mL}$ ) and a blank ethanol control (Sigma-Aldrich; Merck KGaA, Darmstadt, Germany). The regression equation was: $y=1.92 x-0.10$, and the coefficient of correlation $\mathrm{R}^{2}=0.9980$. The results were expressed in $\mathrm{mg}$ $\mathrm{GAE} \cdot \mathrm{g}^{-1}$ extract. All experiments were performed in triplicate.

\subsection{Determination of Individual Polyphenols by LC-MS}

For individual polyphenols identification, two hydroalcoholic extracts of EA were tested. The first extract was obtained in a concentration of $50 \mathrm{mg} / \mathrm{mL}$ after dissolving the extract prepared according to Section 4.1. in $70 \%$ ethanol. The second extract was obtained in a concentration of $10 \mathrm{mg} / \mathrm{mL}$ 
in methanol:water:formic acid $(90: 8: 2, v / v / v)$. For the determination of individual polyphenols, a Shimadzu Chromatograph equipped with SPD-10A UV and LC-MS 2010 detectors was used. The chromatographic conditions were as follows: mobile phases A: water acidified with formic acid at $\mathrm{pH} 3$; $\mathrm{B}$ : acetonitrile acidified with formic acid at $\mathrm{pH} 3$; gradient program: $0.01-20 \mathrm{~min}, 5 \%$ B; $20.01-50 \mathrm{~min}, 5-40 \% \mathrm{~B}$; 50-55 $\mathrm{min}, 40-95 \% \mathrm{~B}$; and $55-60 \mathrm{~min} 95 \% \mathrm{~B}$. The solvent flow rate was $0.3 \mathrm{ml} / \mathrm{min}$ at $20^{\circ} \mathrm{C}$. The monitoring wavelength was $280-320 \mathrm{~nm}$. Two chromatographic columns were used: an Adsorbosphere UHS C18, $5 \mu \mathrm{m}$, Lot no.007250 (Column I) and an EC 150/2 NUCLEODUR C18 Gravity SB $150 \times 2 \mathrm{~mm} \times 5 \mu \mathrm{m}$ column, ref:760618.20, SN E 15110907, Lot 38775055 (Column II). The calibration curves were performed in the range of $20-50 \mu \mathrm{g} / \mathrm{mL}$. The results were expressed in $\mathrm{mg} \cdot \mathrm{g}^{-1} \mathrm{~d} . \mathrm{m}$. Experiments were performed in duplicate. All standards were prepared in methanol (Merck KGaA), and all reagents and solvents used were of analytical grade. Standards of polyphenols were purchased from Sigma-Aldrich, Merck KGaA. The calibration curve and $m / z$ signal are presented in Table 1.

\subsection{Determination of the Total Antioxidant Activity (AA)}

For the determination of the antioxidant activity (AA), the CUPRAC method was employed. The CUPRAC method is a spectrophotometric technique that depends upon the reduction of a cupric neocuproine complex to a cuprous neocuproine complex by a reductant at low $\mathrm{pH}$ [32]. The neocuproine complex can be monitored at $450 \mathrm{~nm}$. As a reference substance, Trolox (6-hydroxy-2,5,7,8-tetramethilcroman-2-carboxylic acid) (Sigma-Aldrich; Merck KGaA, Darmstadt, Germany), an antioxidant with a structure similar to vitamin E, was used. Reagents: $0.01 \mathrm{M}$ $\mathrm{CuCl} 2$ (S.C.Chemical Company S.A., Bucuresti, Romania), $7.5 \times 10^{-3} \mathrm{M}$, neocuproine (2,9-Dimethyl-1,10-phenanthroline) (Sigma-Aldrich, Germany), and acetate buffer. One milliliter $(1 \mathrm{~mL})$ of $0.01 \mathrm{M} \mathrm{CuCl} 2$ solution was mixed with $1 \mathrm{~mL}$ neocuproine $\left(7.5 \times 10^{-3}\right)$ and $1 \mathrm{~mL}$ of acetate buffer. At this solution, $1.1 \mathrm{~mL}$ of sample (alcoholic extract) was added. For the blank, $50 \%$ ethanol was used. The absorption was read after 0.5 hours at $20^{\circ} \mathrm{C}$ at $450 \mathrm{~nm}$. All determinations were performed in triplicate.

\subsection{Determination of Total Alkaloids (TA)}

The determination of total alkaloids (TA) was done using the ninhydrin reaction according the method described by Ibragic and Sofic 2015 [5]. Ninhydrin reacts with aminoacid groups and yields a violet-blue compound with a maximum absorbance at $570 \mathrm{~nm}$. Ninhydrin solution $(2 \%)$ was prepared in ethanol and adjusted to $\mathrm{pH}$ 7.8-7.9 with $\mathrm{Na}_{2} \mathrm{CO}_{3} 6 \mathrm{~g} / \mathrm{L}$. One hundred microliters $(100 \mu \mathrm{L})$ of ninhydrin solution was added to $100 \mu \mathrm{L}$ of extract, obtained as described in Section 4.1., and the volume was filled to $1 \mathrm{~mL}$ with ethanol. The absorbance of the coloured compound was read at $570 \mathrm{~nm}$ using a UV-VIS spectrophotometer (Analytic Jena Specord 205). The calibration curve was obtained from Ephedrine stock solution ( $50 \mathrm{mg} / \mathrm{mL}$, Zentiva SA, Bucuresti, Romania). It was used to obtain serial standard dilution samples in a concentration that ranged between 12 and $32 \mu \mathrm{g} / \mathrm{mL}$. The determinations were performed in triplicate. The coefficient of correlation for the calibration curve was $\mathrm{R}^{2}=0.9547$. The results were expressed in $\mathrm{mg}$ ephedrine/g extract.

\subsection{In Vitro Antimicrobial Activity}

The EA at the concentration of $30 \mu \mathrm{g} / \mathrm{mL}$ was screened for its antimicrobial activity against seven bacterial and two fungus strains. Reference strains see Table 5 . 
Table 5. Reference strains.

\begin{tabular}{ccc}
\hline Bacterial Species & ATCC & Producer \\
\hline Salmonella enterica serotype typhimurium & 14,028 & Thermo Scientific \\
Shigella flexneri serotype 2b & 12,022 & Thermo Scientific \\
Enterococcus faecalis & 51,299 & Thermo Scientific \\
Escherichia coli & 25,922 & Thermo Scientific \\
Klebsiella pneumoniae & 700,603 & Thermo Scientific \\
Pseudomonas aeruginosa & 27,853 & Thermo Scientific \\
Staphylococcus aureus & 25,923 & Thermo Scientific \\
Candida albicans & 10,231 & Thermo Scientific \\
Candida parapsilosis & 22,019 & Thermo Scientific \\
\hline
\end{tabular}

\subsection{Disk Diffusion Method}

The antimicrobial activity of the extract was evaluated, as previously described, by the agar disk diffusion method [33,34]. Mueller-Hinton agar plates (Sanimed, Bucharest, Romania) were inoculated with $100 \mu \mathrm{L}$ of a microbial suspension $\left(10^{8} \mathrm{germs} / \mathrm{mL}\right)$ in physiological saline. Ten microliters, from each sample, were placed on a blank paper disk (BioMaxima, Lublin, Poland), then deposited onto the surface of the cultured media. Agar plates inoculated with the microbial suspensions were incubated at $37{ }^{\circ} \mathrm{C}$ for $24 \mathrm{~h}$. The reading of the inhibition diameters was made in millimeters with a ruler. For all bacterial strains, the disk-diffusion tests were performed in triplicate. The positive control was represented by gentamycin or fluconazole disks (Bio-Rad, Marnes-la-Coquette, France). For the negative control, we used a blank paper disk impregnated with DMSO.

\subsection{Determination of the Minimum Inhibitory Concentration (MIC) and the Minimum Bactericidal Concentration $(M B C)$}

The EA was tested by a broth dilution assay, as recommended by the Clinical Laboratory and Standard Institute (CLSI). A concentration of $200 \mu \mathrm{g} / \mathrm{Ml}$ was prepared. In five test tubes, serial 2-fold dilutions in Mueller-Hinton broth (Sanimed, Bucharest, Romania) of the EA were done. The test tubes were inoculated with $5 \times 10^{5}$ bacteria $/ \mathrm{ml}$. After incubating the test tubes at $37^{\circ} \mathrm{C}$ for $24 \mathrm{~h}$, the MIC (the lowest concentration that yielded no growth) was determined. In addition, the test tubes with no visible growth were inoculated on Columbia agar $+5 \%$ sheep's blood or Sabouraud chloramphenicol agar (Sanimed, Bucharest, Romania) in order to determine the MBC (the lowest concentration that killed $99.9 \%$ of the initial inoculum). The medium plates were incubated at $37^{\circ} \mathrm{C}$ for $24 \mathrm{~h}$, and the MBC was determined [35].

\subsection{Cell Culture}

The cells used in this study were MCF-7 human breast cancer cells purchased from ATCC (American Type Culture Collection; code no ATCC ${ }^{\circledR}$ HTB-22 ${ }^{\mathrm{TM}}$ ) as a frozen vial. The cell line was cultured in specific growth medium Eagle's Minimum Essential Medium (EMEM, code no ATCC $^{\circledR} 30-2003^{\mathrm{TM}}$ ) supplemented with 10\% FBS (fetal bovine serum) and 1\% antibiotics mixture of penicillin/streptomycin (Sigma-Aldrich, Munich, Germany). The cells were maintained in a standard condition: a humidified atmosphere with $5 \% \mathrm{CO}_{2}$ at $37{ }^{\circ} \mathrm{C}$ in a Steri-Cycle i160 incubator (Thermo Fisher Scientific, USA), and supervised daily.

\subsection{Antiproliferative MTT Assay}

The assessment of the antiproliferative activity was conducted as previously described [36]. The cells were plated at a density of 5000 cells/well using 96-well plates and incubated with selected concentrations of EA. After $72 \mathrm{~h}$ of incubation, $5 \mathrm{mg} / \mathrm{mL}$ MTT (3-(4,5-dimethylthiazol-2-yl)-2,5-diphenyltetrazolium bromide) solution was added and incubated for another $4 \mathrm{~h}$. The absorbance of the precipitated formazan crystals dissolved in dimethyl sulfoxide (DMSO) was measured with a microplate reader at $545 \mathrm{~nm}$. 
Wells with cells incubated with medium and DMSO were used as a control [37]. The results are presented as the mean of three different experiments.

\subsection{Anti-Migratory Potential: A Wound Healing Technique}

In order to study the migration of MCF-7 cells after treatment with the EA extract and DMSO, respectively, the in vitro scratch assay method was applied. This is an economical, accessible, and undemanding technique to express cell-to-cell interactions [38,39].

A number of $2 \times 10^{5}$ cells was plated onto a 12-well culture plate and allowed to attach to the bottom of the plate until a confluent cell monolayer was formed. After that, an artificial gap was made with a sterile tip in the middle of each well. All the cellular debris and detached cells were washed with $1.5 \mathrm{~mL}$ PBS/well. Further, the cells were treated with EA extract $(30 \mu \mathrm{g} / \mathrm{mL})$ and DMSO, used in an equal volume, as the test compound. The gap filling was supervised by taking pictures of the scratched area at 0,3 , and $24 \mathrm{~h}$. Photographs were performed at a magnification of $10 \times$ using an inverted microscope (Olympus IX73, Tokyo, Japan) equipped with a DP74 camera. Scratch surfaces were analyzed with the CellSense Dimension software (Version 1.17, Olympus, Tokyo, Japan) and the migration percentage was determined according to the formula described by Felice et al. [40].

\subsection{Determination of the Cytotoxic Potential by the Means of Lactate Dehydrogenase (LDH) Assay}

The cytotoxic rate of the EA extract at the highest concentration $(30 \mu \mathrm{g} / \mathrm{mL})$ was determined by quantification of the LDH leakage into the media when cellular membrane damage emerged. The protocol was almost the same as the one used for the cell viability assessment, with the exception that, on the day of the assay, $50 \mu \mathrm{L}$ from each well was transferred to a new 96-well plate and mixed with reaction mixture $(50 \mu \mathrm{L} /$ well), followed by an incubation of $30 \mathrm{~min}$ at room temperature. After this step, $50 \mu \mathrm{L} /$ well of stop solution was added, and the level of LDH released into the medium was determined by measuring the absorbance of the wells at the wavelengths of $490 \mathrm{~nm}$ and $680 \mathrm{~nm}$ using a microplate reader (xMark ${ }^{\mathrm{TM}}$ Microplate, Biorad). A Positive Control was prepared by combining $1 \mu \mathrm{L}$ of LDH Positive Control with $10 \mathrm{~mL}$ of FCS in PBS (to a final concentration of 1\% FCS).

\subsection{DAPI: Cell Nuclei Staining}

MCF-7 cells cultured in a 6-well plate were stimulated with EA extract $(30 \mu \mathrm{g} / \mathrm{mL})$ for $72 \mathrm{~h}$. At the end of the incubation period, the cells were washed two times with ice-cold PBS and fixed with 4\% paraformaldehyde in PBS for $30 \mathrm{~min}$. Fixed cells were washed again with PBS, permeabilized with 2\% Triton X-100 (Sigma) for 30 min, and blocked with 30\% FCS in $0.01 \%$ Triton X-100 for 1 h. The final step consisted in staining the cells with DAPI $\left(4^{\prime}, 6^{\prime}\right.$-diamidino-2-phenylindole $)$ in a dark chamber for $15 \mathrm{~min}$. Cell nuclei were analyzed at a magnification of $40 \times$ with a fluorescence Olympus IX73 microscope equipped with an integrated DP74 camera (Olympus, Tokyo, Japan).

\subsection{Annexin V-PI Assay}

A number of $5 \times 10^{5}$ cells / well were seeded into a 6-well plate (Greiner bio-one) and left overnight in order to attach to the bottom of the plate. After $24 \mathrm{~h}$, the cultured medium was removed, and a fresh medium containing the tested extracts at a concentration of $30 \mu \mathrm{g} / \mathrm{mL}$ was added. The final concentration of the tested compounds was obtained by successive dilutions into the culture medium, starting from a stock solution of $10 \mathrm{mg} / \mathrm{mL}$ (extract) in DMSO. Untreated cells were used as a control; cells treated with DMSO were used as a solvent control. After $72 \mathrm{~h}$, the cells were trypsinized and analyzed for the apoptotic effect of EA extract using flow cytometry. Annexin V-FITC combined with a propidium iodide (PI) kit (Invitrogen, ThermoFisher, Vienna, Austria) was used in the cell death flow cytometric studies (apoptosis) following the manufacturer's protocol. Briefly, $2-5 \times 10^{5}$ cells were washed two times in $1 \times$ Annexin V Binding Buffer, centrifuged at 1500 RPM for 5 min, resuspended in the binding buffer, and incubated with $5 \mu \mathrm{L}$ of Annexin V-FITC for $15 \mathrm{~min}$ in the dark. After washing the cells with $200 \mu \mathrm{L}$ specific binding buffer and centrifugation, the cell pellet was resuspended in 
$190 \mu \mathrm{L}$ binding buffer, and $10 \mu \mathrm{L}$ of PI solution was added immediately prior to the analysis by flow cytometry. The results are presented as the mean of three different experiments \pm standard deviation.

\subsection{Statistics}

The Prism software package GraphPad Prism 5.01 (GraphPad Software, San Diego, CA, USA) was used for data collection and presentation. The data ranged from three to six separate experiments, and are presented as mean $\pm \mathrm{SD}$. Statistical significance was assessed by one-way ANOVA fallowed by a Newman-Keuls post-hoc test for the comparison of multiple groups. ${ }^{*}, * *, * *$, and ${ }^{* * * *}$ indicate $p<0.05, p<0.01, p<0.001$, and $p<0.0001$, respectively, compared to the control group.

\section{Conclusions}

Ethanolic extracts of the aerial part of Ephedra alata Decne., which is indigenous to the southern part of Tunisia (Djerba), contain polyphenolic phytocompounds and elicit antioxidant activity. The LC-MS results show that, among the screened polyphenolic compounds, the extract contains kaempherol, epicatechin, and quercetin. The extract acts as a bacteriostatic agent against all tested bacterial strains (K. pneumoniae, $\rightarrow$ S. flexneri, S.enterica, $\rightarrow$ E. coli, P.aeruginosa, $\rightarrow$ S. aureus, E. faecalis C. albicans, and .parapsilosis); however, it is bactericidal only against the Gram-positive cocci and Candida spp. In the set of experimental conditions, the hydroalcoholic extract has a potential antiproliferative, pro-apoptotic, and cytotoxic effect against the MCF-7 human breast cancer cell line.

Author Contributions: C.D. conceived the study, analyzed the data, and drafted the work; E.A., S.P., O.C. performed the phytochemical analysis, and validated and analyzed the data; D.M. (Delia Muntean) performed the antimicrobial analysis, and validated and analyzed the data; C.F., C.O., A.B. V.B., I.Z., and M.P. performed the in vitro tests on the human breast cancer cell line, and validated and analyzed the data; D.M. (Daliana Minda), C.S. edited the manuscript; M.H., C.A.D. reviewed and supervised the work.

Funding: This research was funded by the University of Medicine and Pharmacy "Victor Babeş", Eftimie Murgu Square, No. 2, 300041 Timişoara, România. Some experiments were also performed at the Interdisciplinary Research Platform belonging to Banat University of Agricultural Sciences and Veterinary Medicine 'King Michael I of Romania' from Timişoara, Romania.

Conflicts of Interest: The authors declare no conflict of interest.

\section{References}

1. Atanasov, A.G.; Waltenberger, B.; Pferschy-Wenzig, E.-M.; Linder, T.; Wawrosch, C.; Uhrin, P.; Temml, V.; Wang, L.; Schwaiger, S.; Heiss, E.H.; et al. Discovery and resupply of pharmacologically active plant-derived natural products: A review. Biotechnol. Adv. 2015, 33, 1582-1614. [CrossRef] [PubMed]

2. Rydin, C.; Pedersen, K.R.; Crane, P.R.; Friis, E.M. Former diversity of Ephedra (Gnetales): Evidence from Early Cretaceous seeds from Portugal and North America. Ann. Bot. 2006, 98, 123-140. [CrossRef] [PubMed]

3. Hegazi, G.A.E.M.; El-Lamey, T.M. In vitro production of some phenolic compounds from Ephedra alata Decne. J. Appl. Environ. Biol. Sci. 2011, 1, 158-163.

4. Caveney, S.; Charlet, D.A.; Freitag, H.; Maier-Stolte, M.; Starratt, A.N. New observations on the secondary chemistry of world Ephedra (Ephedraceae). Am. J. Bot. 2001, 88, 1199-1208. [CrossRef]

5. Ibragic, S.; Sofić, E. Chemical composition of various Ephedra species. Bosn. J. Basic Med. Sci. 2015, 15, 21-27. [CrossRef] [PubMed]

6. Abourashed, E.A.; El-Alfy, A.T.; Khan, I.A.; Walker, L. Ephedra in perspective-A current review. Phytother. Res. 2003, 17, 703-712. [CrossRef] [PubMed]

7. Magalhães, E.; Govêia, C.S.; Ladeira, L.C.d.A.; Nascimento, B.G.; Kluthcouski, S.M.C. Ephedrine versus phenylephrine: Prevention of hypotension during spinal block for cesarean section and effects on the fetus. Braz. J. Anesthesiol. 2009, 59, 11-20. [CrossRef]

8. Cocan, I.; Alexa, E.; Danciu, C.; Radulov, I.; Galuscan, A.; Obistioiu, D.; Morvay, A.A.; Sumalan, R.M.; Poiana, M.A.; Pop, G.; et al. Phytochemical screening and biological activity of Lamiaceae family plant extracts. Exp. Ther. Med. 2018. [CrossRef] 
9. Jerbi, A.; Zehri, S.; Abdnnabi, R.; Gharsallah, N.; Kammoun, M. Essential oil composition, free-radical-scavenging and antibacterial effect from stems of Ephedra alata alenda in Tunisia. J. Essent. Oil Bear. Plants 2016, 19, 1503-1509. [CrossRef]

10. Parsaeimehr, A.; Sargsyan, E.; Javidnia, K. A comparative study of the antibacterial, antifungal and antioxidant activity and total content of phenolic compounds of cell cultures and wild plants of three endemic species of Ephedra. Molecules 2010, 15, 1668-1678. [CrossRef]

11. Khan, A.; Jan, G.; Khan, A.; Gul Jan, F.; Bahadur, A.; Danish, M. In vitro antioxidant and antimicrobial activities of Ephedra gerardiana (root and stem) crude extract and fractions. Evid.-Based Complement. Altern. Med. 2017. [CrossRef] [PubMed]

12. Pullela, S.V.; Takamatsu, S.; Khan, S.I.; Khan, IA. Isolation of lignans and biological activity studies of Ephedra viridis. Planta Med. 2005, 71, 789-791. [CrossRef] [PubMed]

13. Nam, N.-H.; Lee, C.-W.; Hong, D.-H.; Kim, H.-M.; Bae, K.-H.; Ahn, B.-Z. Antiinvasive, antiangiogenic and antitumour activity of Ephedra sinica extract. Phytother. Res. 2003, 17, 70-76. [CrossRef] [PubMed]

14. Mohamad, N.; Falah, A.; Fatima, J.; Hussein, K.; Akram, H.; Ali, C.; Hassan, R. Antibacterial, antioxidant and antiproliferative activities of the hydroalcoholic extract of the lebanese plant: Ephedra Campylopoda. Int. Res. J. Pharm. 2016, 7, 23-29. [CrossRef]

15. Attard, E.; Vella, K. Effects of ephedrine and Ephedra fragilis crude extracts on human peripheral lymphocytes. Pharmacogn. Res. 2009, 1, 38-42.

16. Al-Qarawi, A.A.; Abd-Allah, E.F.; Hashem, A. Ephedra alata as biologically-based strategy inhibit aflatoxigenic seedborne mold. Afr. J. Microbiol. Res. 2011, 5, 2297-2303. [CrossRef]

17. Jaradat, N.; Hussen, F.; Anas, A.A. Preliminary phytochemical screening, quantitative estimation of total flavonoids, total phenols and antioxidant activity of Ephedra alata Decne. J. Mater. Environ. Sci. 2015, 6, 1771-1778.

18. Al-Rimawi, F.; Abu-Lafi, S.; Abbadi, J.; Alamarneh, A.A.A.; Sawahreh, R.A.; Odeh, I. Analysis of phenolic and flavonoids of wild Ephedra alata plant extracts by LC/PDA and LC/MS and their antioxidant activity. Afr. J. Tradit. Complement. Altern. Med. 2017, 14, 130-141. [CrossRef]

19. Amakura, Y.; Yoshimura, M.; Yamakami, S.; Yoshida, T.; Wakana, D.; Hyuga, M.; Hyuga, S.; Hanawa, T.; Goda, Y. Characterization of Phenolic Constituents from Ephedra Herb Extract. Molecules 2013, 18, 5326-5334. [CrossRef]

20. Ziani, B.E.C.; Heleno, S.A.; Bachari, K.; Dias, M.I.; Ferreira, I.C.F. Phenolic compounds characterization by LC-DAD-ESI/MSn and bioactive properties of Thymus algeriensis Boiss. \& Reut. and Ephedra alata Decne. Food Res. Int. 2018. [CrossRef]

21. Grippo, A.A.; Capps, K.; Rougeau, B.; Gurley, B.J. Analysis of flavonoid phytoestrogens in botanical and ephedra-containing dietary supplements. Ann. Pharmacother. 2007, 41, 1375-1382. [CrossRef] [PubMed]

22. Ghanem, S.; El-Magly, U.I.A. Antimicrobial activity and tentative identification of active compounds from the medicinal Ephedra alata male plant. J. Taibah Univ. Med. Sci. 2008, 3, 7-15. [CrossRef]

23. Chebouat, E.; Dadamoussa, B.; Gharabli, S.; Gherraf, N.; Allaoui, M.; Cheriti, A.; Lahham, A.; Zellagui, A. Assessment of antimicrobial activity of flavonoids extract from Ephedra alata. Der Pharmacia Lettre 2014, 6, 27-30.

24. Al-Awaida, W.; Al-Hourani, B.J.; Akash, M.; Talib, W.H.; Zein, S.; Falah, R.R. In vitro anticancer, anti-inflammatory, and antioxidant potentials of Ephedra aphylla. J. Cancer Res. Ther. 2018. [CrossRef] [PubMed]

25. Kallassy, H.; Fayyad-Kazan, M.; Makki, R.; EL-Makhour, Y.; Rammal, H.; Leger, D.Y.; Sol, V.; Fayyad-Kazan, H.; Liagre, B.; Badran, B. Chemical composition and antioxidant, anti-inflammatory, and antiproliferative activities of Lebanese Ephedra Campylopoda plant. Med. Sci. Monit. Basic Res. 2017, 23, 313-325. [CrossRef] [PubMed]

26. Oshima, N.; Yamashita, T.; Hyuga, S.; Hyuga, M.; Kamakura, H.; Yoshimura, M.; Maruyama, T.; Hakamatsuka, T.; Amakura, Y.; Hanawa, T.; et al. Efficiently prepared ephedrine alkaloids-free Ephedra Herb extract: A putative marker and antiproliferative effects. J. Nat. Med. 2016, 70, 554-562. [CrossRef] [PubMed]

27. Kmail, A.; Lyoussi, B.; Zaid, H.; Saad, B. In vitro assessments of cytotoxic and cytostatic effects of Asparagus aphyllus, Crataegus aronia, and Ephedra alata in monocultures and co-cultures of Hepg2 and THP-1-derived macrophages. Pharmacogn. Commun. 2017, 7, 24-33. [CrossRef]

28. Mendelovich, M.; Shoshan, M.; Fridlender, M.; Mazuz, M.; Namder, D.; Nallathambi, R.; Selvaraj, G.; Kumari, P.; Ion, A.; Wininger, S.; et al. Effect of Ephedra foeminea active compounds on cell viability and actin structures in cancer cell lines. J. Med. Plant Res. 2017, 11, 690-702. [CrossRef] 
29. Jaradat, N.A.; Shawahna, R.; Eid, A.M.; Al-Ramahi, R.; Asma, M.K.; Zaid, AN. Herbal remedies use by breast cancer patients in the West Bank of Palestine. J. Ethnopharmacol. 2016, 1-8. [CrossRef]

30. Jaradat, N.A.; Al-Ramahi, R.; Zaid, A.N.; Ayesh, O.I.; Eid, A.M. Ethnopharmacological survey of herbal remedies used for treatment of various types of cancer and their methods of preparations in the West Bank-Palestine. BMC Complement. Altern. Med. 2016, 16, 93. [CrossRef]

31. Abu-Darwish, M.S.; Efferth, T. Medicinal plants from Near East for cancer therapy. Front. Pharmacol. 2018, 9, 56. [CrossRef] [PubMed]

32. Atak, M.; Mavi, K.; Uremis, I. Bio-herbicidal effects of oregano and rosemary essential oils on germination and seedling growth of bread wheat cultivars and weeds. Rom. Biotechnol. Lett. 2016, 21, 11149-11159.

33. Pavel, I.Z.; Danciu, C.; Oprean, C.; Dehelean, C.A.; Muntean, D.; Csuk, R.; Muntean, D.M. In vitro evaluation of the antimicrobial ability and cytotoxicity on two melanoma cell lines of a benzylamide derivative of maslinic acid. Anal. Cell. Pathol. (Amst.) 2016, 2016, 2787623. [CrossRef] [PubMed]

34. Oprean, C.; Zambori, C.; Borcan, F.; Soica, C.; Zupko, I.; Minorics, R.; Bojin, F.; Ambrus, R.; Muntean, D.; Danciu, C.; et al. Anti-proliferative and antibacterial in vitro evaluation of the polyurethane nanostructures incorporating pentacyclic triterpeneS. Pharm. Biol. 2016, 54, 2714-2722. [CrossRef] [PubMed]

35. Wikler, M.A.; Low, D.E.; Cockerill, F.R.; Sheehan, D.J.; Craig, W.A.; Tenover, F.C. Methods for Dilution Antimicrobial Susceptibility Tests for Bacteria That Grow Aerobically; Approved Standard, 7th, ed.; Document M7-A7; CLSI: Wayne, PA, USA, 2006.

36. Szabó, J.; Jerkovics, N.; Schneider, G.; Wölfling, J.; Bózsity, N.; Minorics, R.; Zupkó, I.; Mernyák, E. Synthesis and in vitro antiproliferative evaluation ofC-13 epimers of triazolyl-D-secoestrone alcohols: The first potent 13a-D-secoestrone derivative. Molecules 2016, 21, 611. [CrossRef]

37. Mosmann, T. Rapid colorimetric assay for cellular growth and survival: Application to proliferation and cytotoxicity assays. J. Immunol. Methods 1983, 65, 55-63. [CrossRef]

38. Liang, C.C.; Park, A.Y.; Guan, J.L. In vitro scratch assay: A convenient and inexpensive method for analysis of cell migration in vitro. Nat. Protoc. 2007, 2, 329-333. [CrossRef]

39. Moacă, E.A.; Farcaş, C.; Ghiţu, A.; Coricovac, D.; Popovici, R.; Cărăba-Meiţă, N.L.; Ardelean, F.; Antal, D.S.; Dehelean, C.; Avram, Ş. A Comparative Study of Melissa officinalis Leaves and Stems Ethanolic Extracts in terms of Antioxidant, Cytotoxic, and Antiproliferative Potential. Evid. Based Complement. Alternat. Med. 2018, 7860456. [CrossRef]

40. Felice, F.; Zambito, Y.; Belardinelli, E.; Fabiano, A.; Santoni, T.; Di Stefano, R. Effect of different chitosan derivatives on in vitro scratch wound assay: A comparative study. Int. J. Biol. Macromol. 2015, 76, $236-241$. [CrossRef]

Sample Availability: Samples of the compounds are available from the authors.

(C) 2018 by the authors. Licensee MDPI, Basel, Switzerland. This article is an open access article distributed under the terms and conditions of the Creative Commons Attribution (CC BY) license (http:/ / creativecommons.org/licenses/by/4.0/). 